\title{
THE BIOLOGY OF THE LEAF MARK POLYMORPHISM IN TRIFOLIUM REPENS L.
}

\section{DISTRIBUTION OF PHENOTYPES AT A LOCAL SCALE}

\author{
M. G. CAHN* and J. L. HARPER \\ School of Plant Biology, University College of North Wales, Bangor, Gwynedd \\ Received 18.xi.75
}

\begin{abstract}
SUMMARY
The distribution of the white leaf mark polymorphism of Trifolium repens $\mathrm{L}$. was studied in a lowland pasture in North Wales and in a series of $1 \mathrm{~m}^{2}$ quadrats elsewhere in Britain. Each quadrat was subdivided into $10 \times 10 \mathrm{~cm}$ quadrats to allow the study of pattern. The number of morphs found in a $10 \mathrm{~cm}$ square was in the range $1 \cdot 5-6 \cdot 0$ with a mean value of $4 \cdot 16$. In a 5-year-old seeded ley the mean was $2 \cdot 75$. The populations consist of a large number of morphs intimately mixed. The frequency distribution of morphs per quadrat differs strikingly from the frequency distribution of species suggesting that some selective force operates to prevent any morphs from dominating the sward even on a local scale. The frequency of morphs bearing leaf marks decreased with increasing grass length suggesting a relationship with grazing. There is a seasonal pattern in the expression of the leaf mark phenotypes and the floristic diversity of such a pasture is therefore represented at three levels, (a) the species present, $(b)$ the genotypes present within each species and (c) the various phenotypic expressions of these genotypes.
\end{abstract}

\section{INTRODUCTION}

WITHIN plant populations diversity appears at three levels, $(a)$ the diversity of species present in the area, $(b)$ the genetic diversity within each species and $(c)$ phenotypic diversity represented by ages and plasticity of the genotypes present. Populations of white clover (Trifolium repens) are characteristically polymorphic for white leaf marks. The white marks appear as bands on the laminae as a result of air spaces within the palisade tissue. Two linked groups of genes control leaf marking in T. repens (Corkill, 1971); the white leaf marks are controlled by multiple alleles at a locus in one of these groups (Brewbaker, 1955; Carnahan et al., 1955). Seven major alleles are commonly present in natural populations and genotypes can often be identified by the specific pattern of the phenotypic white leaf mark provided that this is fully expressed (see table 1). These leaf marks, together with other leaf characters have been used to identify clones of Trifolium repens in the field (Harberd, 1963).

In a study of this polymorphism over the natural range of the species (partly based on herbarium material) Pusey (1965) found that the frequencies of the alleles showed gentle clines, the major one being from north Scotland to Afghanistan. However, the existence of clines does not explain the existence of polymorphism. It is doubtful indeed if any extensive survey

* Present address: c/o County Planning Officer, West Glamorgan County Council, Planning Department, 12 Orchard Street, Swansea, West Glamorgan.

$37 / 3-A$ 
procedure can reveal the nature of the real factors that balance the survivorship of morphs in a balanced polymorphic system particularly in perennial species. More detailed analysis, with or without perturbation, may be needed to isolate the real events that determine the life and death of individuals.

TABLE 1

Classification of leaf mark used in this paper

Leaf mark

(1) Unmarked

(2) Marked

(a) Simple mark

(b) Point*

(c) Double simple mark

(d) Broken Yellow

(e) Broken Yellow/Simple mark

(f) Basal

(g) Basal/Simple mark

(h) Filled

(i) Filled/Simple mark

(j) Filled/Broken Yellow mark

(k) Broken

(l) Distal

\section{Abbreviation}

used

$\mathrm{O}$

L

L

LL

Y

YL

$\mathrm{Ba}$

$\mathrm{BaL}$

F

FL

FY

B

$\mathbf{X}$

* The "point" phenotype has been aggregated with the "simple mark" phenotype since simple marks frequently appear identical to "point" marks in the field.

This paper describes the intra-specific genetic diversity of some populations of Trifolium repens set in the context of the diversity of species and the phenotypic variation within a localised area.

\section{Materials AND methods}

Most of the studies reported in this paper were made on a field of permanent grassland at Henfaes, Aber, Gwynedd in N. Wales. The history and management of this pasture have been described in Sarukhán and Harper (1973). Some additional surveys were made on permanent grasslands in other parts of Britain for comparison with the Henfaes pasture.

\section{(i) Toe-point survey}

A survey was made to discover what variation in the frequency of phenotypes occurred within the field at Henfaes and to determine if this was correlated with grass length or grazing intensity. Samples were taken every three paces across the field and every five paces along the field. The results were then grouped into areas (Cahn, 1976) which are described in table 2. Sampling (which followed the procedure of Pusey, 1965) involved finding the clover leaf nearest to a mark on the shoe and this was determined at each sample point. If there was no clover leaf within $7 \frac{1}{2} \mathrm{~cm}$ radius no sample was taken.

Stolons of marked plants occasionally produced unmarked leaves so, when a phenotypically unmarked leaf was found, the stolon was followed backwards 
and the other leaves checked for the presence of a mark. The field had recently been grazed by sheep and cattle. The grass length at each sample point was recorded on a 4 point scale: 1 , well grazed $<7.5 \mathrm{~cm}$; 2 , lightly grazed $7 \cdot 5-15.0 \mathrm{~cm} ; 3$, ungrazed (more than $15 \mathrm{~cm}$ ); 4, within $15 \mathrm{~cm}$ of a thistle (Cirsium arvense).

TABLE 2

Characters of areas in Henfaes field, Aber, Gwynedd

\begin{tabular}{cll} 
Area & \multicolumn{1}{c}{ Character } & \multicolumn{1}{c}{ Topography } \\
A & Short grass & Level \\
B & Short grass & Level, dips near railway \\
C & Long grass + Cirsium arvense & Level \\
D & Long grass + Cirsium arvense & Level \\
E & Short grass & Level \\
F & Short grass & Dips near stone \\
G & Long grass +Cirsium arvense & Level \\
H & Long grass +Cirsium arvense & Level \\
J & Short grass & Level \\
K & Intermediate & Ridge \\
L & Intermediate-Short & Hollow \\
M & Long grass & Level
\end{tabular}

\section{(ii) Detailed mapping of permanent quadrats}

The distribution of clover morphs was studied in 12 permanent $1 \mathrm{~m} \mathrm{sq}$ quadrats (A1-G1, A2-E2) in the field between August 1971 and August 1972, and an analysis of the floristics of these quadrats was made in 1973. Five of the 12 quadrats were sited in lightly grazed and seven in heavily

TABLE 3

Sites of mapping quadrats

\begin{tabular}{|c|c|c|c|c|c|}
\hline Site & $\begin{array}{l}\text { No. of } \\
\text { quadrats } \\
\left(1 \mathrm{~m}^{2}\right)\end{array}$ & $\begin{array}{c}\text { Quadrat } \\
\text { titles }\end{array}$ & Habitat/management & $\begin{array}{c}\text { Last } \\
\text { cultivated }\end{array}$ & $\begin{array}{l}\text { No. of } \\
\text { clones/ } \\
10 \mathrm{~cm}^{2}\end{array}$ \\
\hline $\begin{array}{l}\text { Cae Cwrtiau, } \\
\text { Aber }\end{array}$ & 2 & $\mathrm{CCl}-2$ & Ley & 1968 & $2 \cdot 75$ \\
\hline $\begin{array}{l}\text { Lugg Meadows } \\
\text { Hereford }\end{array}$ & 2 & LM1-2 & $\begin{array}{l}\text { Common land. } \\
\text { Grazed Sept.-Dec. } \\
\text { Cut of hay June-July }\end{array}$ & Before 1750 & $1 \cdot 61$ \\
\hline $\begin{array}{l}\text { Walland Marsh, } \\
\text { Rye, Sussex }\end{array}$ & 3 & Rl-3 & $\begin{array}{l}\text { Paddock on sheep farm. } \\
\text { Intermittent grazing }\end{array}$ & $\begin{array}{l}\text { Never in living } \\
\text { memory }\end{array}$ & $2 \cdot 81$ \\
\hline $\begin{array}{l}\text { Port Meadow, } \\
\text { Oxford }\end{array}$ & 4 & PM1-4 & $\begin{array}{l}\text { Common land. } \\
\text { Grazed water meadow }\end{array}$ & Before 1086 & 3.54 \\
\hline $\begin{array}{l}\text { Henfaes, Aber, } \\
\text { Gwynedd }\end{array}$ & 12 & $\begin{array}{l}\mathrm{A} 1-\mathrm{G} 1 \\
\mathrm{~A} 2-\mathrm{E} 2\end{array}$ & $\begin{array}{l}\text { Paddock. } \\
\text { Intermittent grazing }\end{array}$ & Never in memory & $4 \cdot 16$ \\
\hline
\end{tabular}

grazed areas of the field. At each site four pieces of steel electric conduit tubing $(1.9 \times 30 \mathrm{~cm})$ were sunk vertically into the ground. These allowed accurate placement of a large quadrat $(1.20 \times 1.20 \mathrm{~m})$ which had, at its corners, supports made of pieces of conduit tube $(1.6 \times 40 \mathrm{~cm})$ which fitted tightly into the buried tubes. The quadrats were removed after each mapping operation and the sunken tubes marked with pieces of coloured 


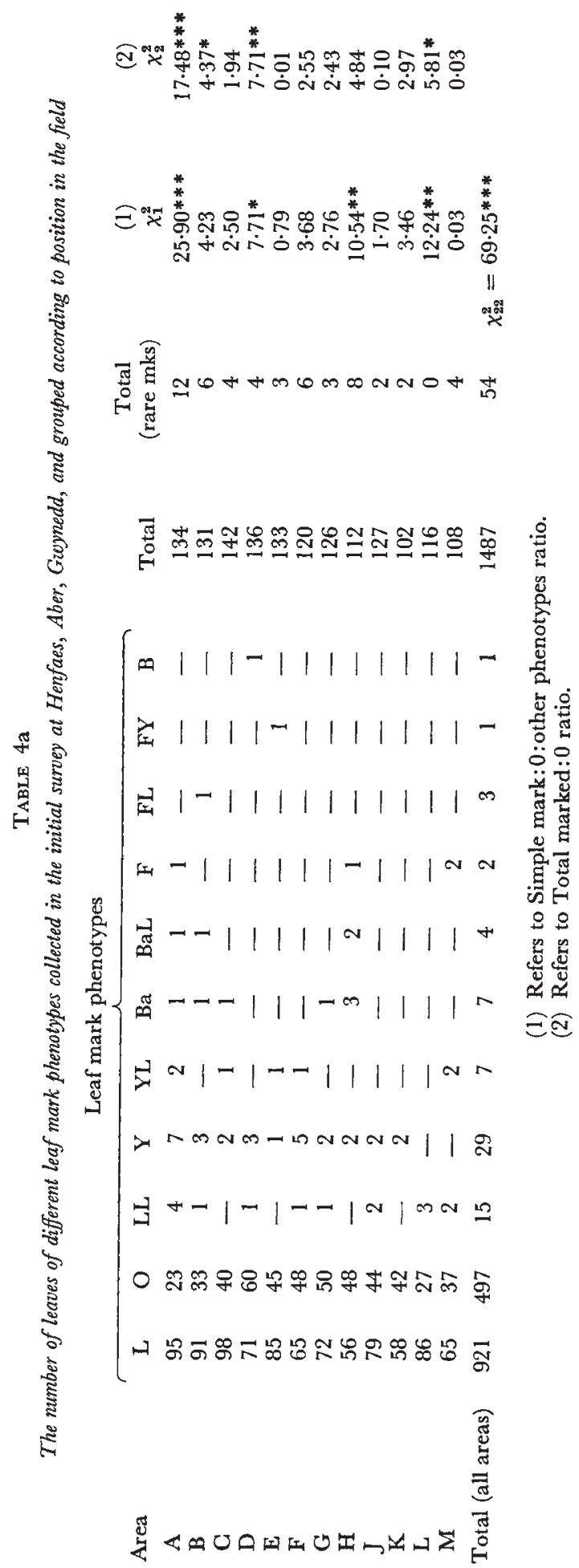


marine twine. Each quadrat was subdivided into $10010 \times 10 \mathrm{~cm}$ subquadrats. The technique allowed accurate re-siting of the quadrats at each time of observation and permitted repeated study of the same sites without seriously disturbing the vegetation of the quadrat: nothing except the marking string protruded above the ground that might affect the behaviour of grazing animals. The marking string disappeared on occasions and the buried tubes were then relocated with a metal detector. For accurate mapping of individual plants a small $10 \mathrm{~cm}$ sq quadrat was suspended from the large quadrat.

The number of morphs present was recorded in each of the $10 \mathrm{~cm}^{2}$ quadrats. The density of clover was recorded on a three-point scale and records were also made of flowers, seedlings and any obvious signs of disease.

(iii) Analysis of the distribution of the leaf morphs present in five grassland sites in other parts of England and Wales

During late June 1973 the pattern of distribution of leaf mark morphs was studied in a variety of grassland fields listed in table 3 in order to set the results found at Henfaes in a wider context.

(iv) The growth of plants of different leaf mark phenotypes in a cool greenhouse

Core soil samples $2.5 \mathrm{~cm}$ diameter were collected in November 1971 from the corners of each of the 12 permanent quadrats in the field at Henfaes. The stolons of $T$. repens in the vegetation covering the core were propagated in a heated greenhouse and classified into leaf mark phenotypes.

\section{Results}

(i) Toe-point survey.

The results of this survey are given in tables 4 and 5 . Chi-squared values were determined from $2 \times n$ contingency tables. The proportions of the

TABLE $4 \mathrm{~b}$

Leaf mark phenotypes in long and short grass areas at Henfaes, Aber, Gwynedd

\begin{tabular}{|c|c|c|c|c|c|}
\hline & $\mathrm{L}$ & $\mathrm{LL}$ & Y \& YL & Other marks & \\
\hline $\begin{array}{l}\text { Long grass areas } \\
\quad(\mathrm{C}, \mathrm{D}, \mathrm{G}, \mathrm{H}, \mathrm{K}, \mathrm{M})\end{array}$ & $409(449 \cdot 66)$ & $11(7 \cdot 32)$ & $22(17 \cdot 58)$ & $7(8 \cdot 79)$ & $277(242 \cdot 65)$ \\
\hline Short grass areas & $512(471 \cdot 34)$ & $4(7 \cdot 68)$ & $14(18 \cdot 42)$ & $11(9 \cdot 21)$ & $220(254 \cdot 35)$ \\
\hline $\begin{array}{l}\text { (A, B, } \mathbf{L}, \mathbf{r}, \mathbf{J}, \mathbf{L}) \\
\text { Total }\end{array}$ & 921 & 15 & 36 & 18 & 497 \\
\hline
\end{tabular}

different morphs present differed significantly in different areas of the fieldlargely because of local high frequencies of the rarer phenotypes (table 4a). This indicates that the leaf mark phenotypes scored are not distributed at random in the sample area. When all those leaves bearing marks were grouped together and the ratio of unmarked leaves was considered, significant differences also appeared between positions in the field (table 4a, column 2). 


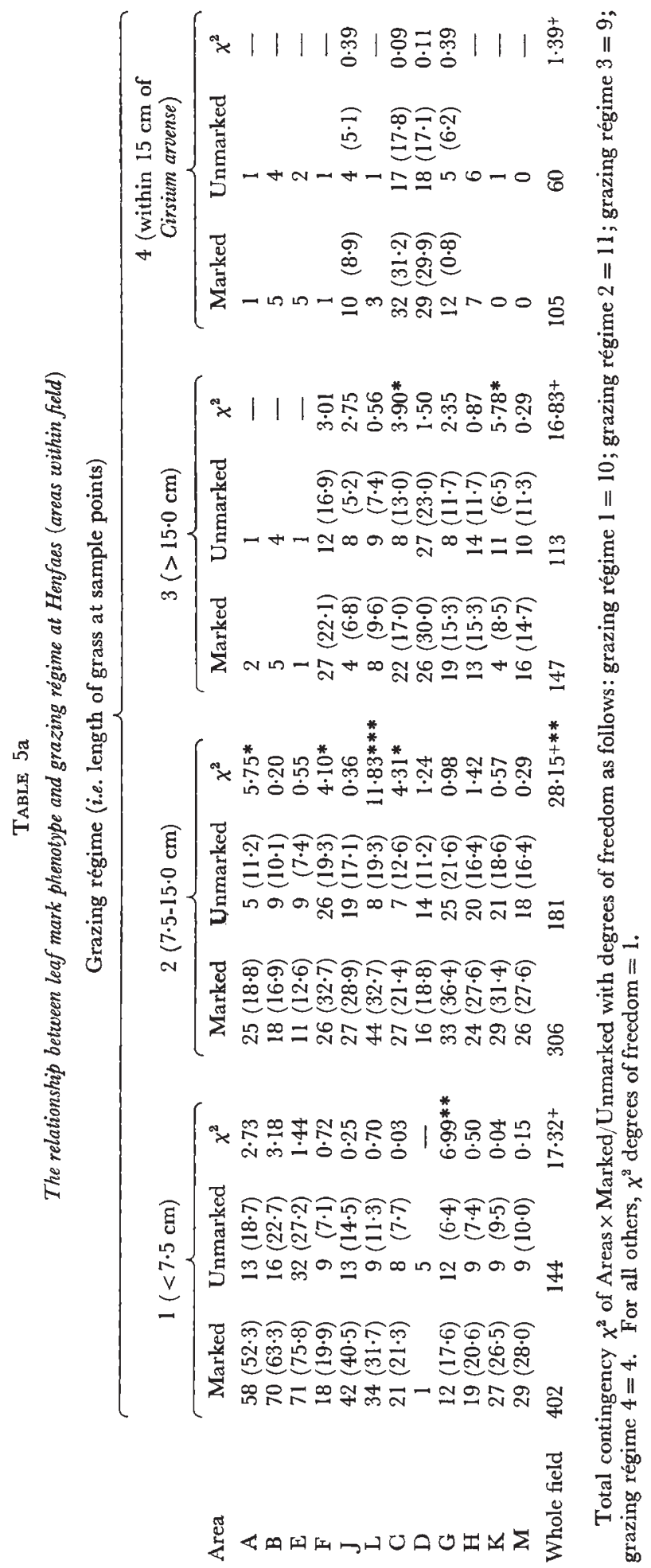


TABLE $5 \mathrm{~b}$

The relationship between leaf mark phenotype and grazing at Henfaes (whole field)

Grazing régime

2

3

4

Marked
$402(359 \cdot 5)$
$306(320 \cdot 7)$
$147(171 \cdot 2)$
$105(108 \cdot 6)$

Unmarked
$144(186 \cdot 5)$
$181(166 \cdot 3)$
$113(88 \cdot 8)$
$60(56 \cdot 4)$

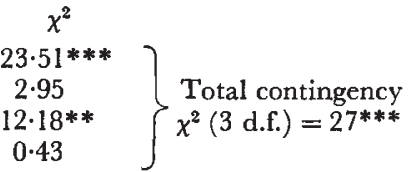

Expected values in brackets.

TABLE 5c

The relationship between morph frequency and the nature of the area at different localised grazing intensities (expected values in brackets)

Grazing régime (i.e. length of grass at sample point)

Character of the area

Short grass sites

(A, B, E, F, J, L)

Long grass sites

(C, D, G, H, K, M)

$\chi^{2}(1$ d.f. $)$
2

\begin{tabular}{|c|c|c|c|c|c|c|c|}
\hline \multicolumn{2}{|r|}{1} & \multicolumn{2}{|c|}{2} & \multicolumn{2}{|c|}{3} & \multicolumn{2}{|c|}{4} \\
\hline Marked & Unmarked & $\mathbf{M}$ & U & $\mathbf{M}$ & $\mathrm{U}$ & $\mathbf{M}$ & $\mathrm{U}$ \\
\hline $\begin{array}{l}293 \\
(283 \cdot 5) \\
109 \\
(118 \cdot 5)\end{array}$ & $\begin{array}{c}92 \\
(101 \cdot 5) \\
52 \\
(42 \cdot 5)\end{array}$ & $\begin{array}{c}151 \\
(142 \cdot 6) \\
155 \\
(163 \cdot 4)\end{array}$ & $\begin{array}{l}76 \\
(84 \cdot 4) \\
105 \\
(96 \cdot 6)\end{array}$ & $\begin{array}{c}47 \\
(46 \cdot 4) \\
100 \\
(100 \cdot 6)\end{array}$ & $\begin{array}{c}35 \\
(35 \cdot 6) \\
78 \\
(77 \cdot 4)\end{array}$ & $\begin{array}{c}25 \\
(24 \cdot 2) \\
80 \\
(80 \cdot 8)\end{array}$ & $\begin{array}{c}13 \\
(13 \cdot 8) \\
47 \\
(46 \cdot 2)\end{array}$ \\
\hline \multicolumn{2}{|c|}{$\chi^{2}=4 \cdot 13^{*}$} & \multicolumn{2}{|c|}{$\chi^{2}=2 \cdot 49$} & \multicolumn{2}{|c|}{$\chi^{2}=0.04$} & \multicolumn{2}{|c|}{$\chi^{2}=0 \cdot 10$} \\
\hline
\end{tabular}

Totals for all grazing régimes

\begin{tabular}{|c|c|}
\hline Marked & Unmarked \\
\hline $\begin{array}{c}449 \\
(483 \cdot 4) \\
541 \\
(506 \cdot 7)\end{array}$ & $\begin{array}{c}277 \\
(242 \cdot 6) \\
220 \\
(254 \cdot 3)\end{array}$ \\
\hline
\end{tabular}

$\chi^{2}(1$ d.f. $)=14 \cdot 27 * * *$.

$*=\mathrm{P}<0.05 . \quad * *=\mathrm{P}<0.01 \quad * * *=\mathrm{P}<0.001$.

When the long grass areas $(\mathrm{A}, \mathrm{B}, \mathrm{E}, \mathrm{F}, \mathrm{J}, \mathrm{L})$ and short grass areas $(\mathrm{C}, \mathrm{D}, \mathrm{G}$, $\mathrm{H}, \mathrm{K}, \mathrm{M})$ were summed separately, there was clear evidence $(\mathrm{P}<0.001)$ of a significant difference between the two groups. The significant chi-squared value in table $4 \mathrm{~b}$ largely represents an excess of unmarked leaves in long grass areas and of marked leaves in the shorter grass.

At each toe sample the height of grass had been determined in four categories. The frequency of marked and unmarked leaves could therefore be compared with the grass lengths (table 5 ). The ratio of marked to unmarked leaves (values summed over areas) changed from 2.79 in grass less than $7.5 \mathrm{~cm}$ high, to 1.69 in grass $7.5-15.0 \mathrm{~cm}$ high and to 1.30 in grass more than $15 \mathrm{~cm}$ high. The ratio close to thistles, which tend to protect against grazing, was $1 \cdot 65$.

\section{(ii) Detailed maps of permanent quadrats}

The preparation of detailed maps of morphs was complicated by the frequent failure of leaves to express their mark phenotype. Unmarked clones 
were recorded in a high proportion of the quadrats. The clarity of marks varies through the year-they are clearest between April and July and least expressed in December and January. An estimate of the seasonal variation in expression was obtained by comparing the frequency with which phenotypes were recorded through the year within the $10 \mathrm{~cm}^{2}$ sub-quadrats of a $1 \mathrm{~m}$ sq quadrat. These values are shown for an annual cycle in fig. l. The maximum number of clones was usually distinguishable in May, June or July followed by a sudden decline to a lower figure. A comparable cycle in the expression of the leaf marks occurred when plants were grown in a cool
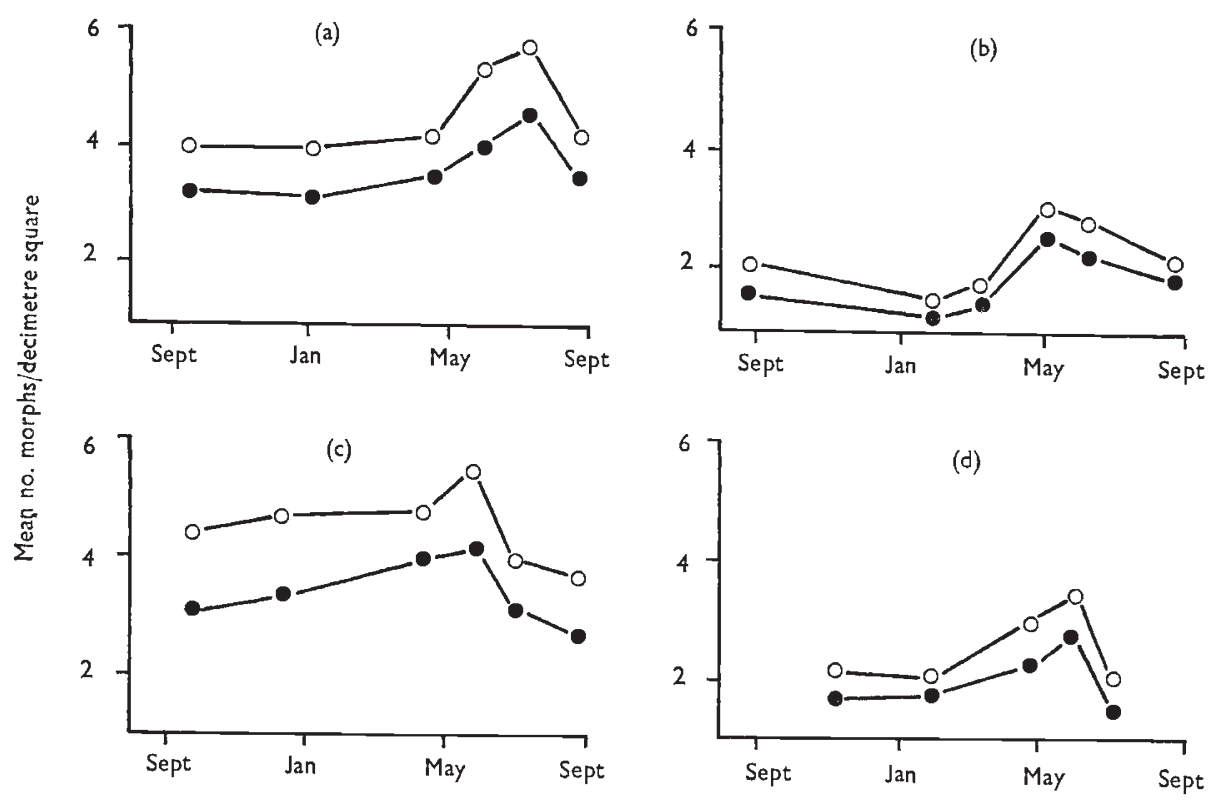

FIG. 1.-Seasonal variation in the mean number of phenotypes recognisable per $100 \mathrm{~cm}^{2}$ quadrat at Henfaes, Aber, Gwynedd. $O=$ maximum estimate; $O=$ minimum estimate (see text).

greenhouse. Not all the phenotypes followed a similar cycle in the fielddifferent morphs varied in the time of year at which they were clearest and most readily recognised (fig. 2).

The periodicity of expression of leaf marks introduced some problems in identifying clones and two sets of results were therefore produced-maximum and minimum estimates. In the maximum estimate all the phenotypes that might represent separate morphs were counted separately. In the minimum estimate only those phenotypes were counted for which there was indubitable evidence (difference in leaf mark) that they belonged to separate clones. The difference between the two estimates was greater at Henfaes than at the other sites.

An estimate was made of the number of morphs present in different sizes of quadrat. The resulting morph-area curves are plotted in fig. 3 (see Cahn, 1976). The accuracy with which clones had been identified in the field was checked against the identification of clones from the soil cores which had been propagated in the greenhouse. Wholly accurate identification of these 
samples was possible during the period of culture. These accurate identifications were plotted on the morph-area curve obtained in the field. Both the sample and quadrat sizes were very small and large variations are to be expected. However, in nine of the 12 quadrats the accurate laboratory glasshouse results conformed closely to expectations based on field sampling. In three quadrats, at Henfaes; C1, E2 and G1, the number of accurately identified morphs from the core samples was markedly lower than expectation based on field data. These three quadrats were in relatively dense

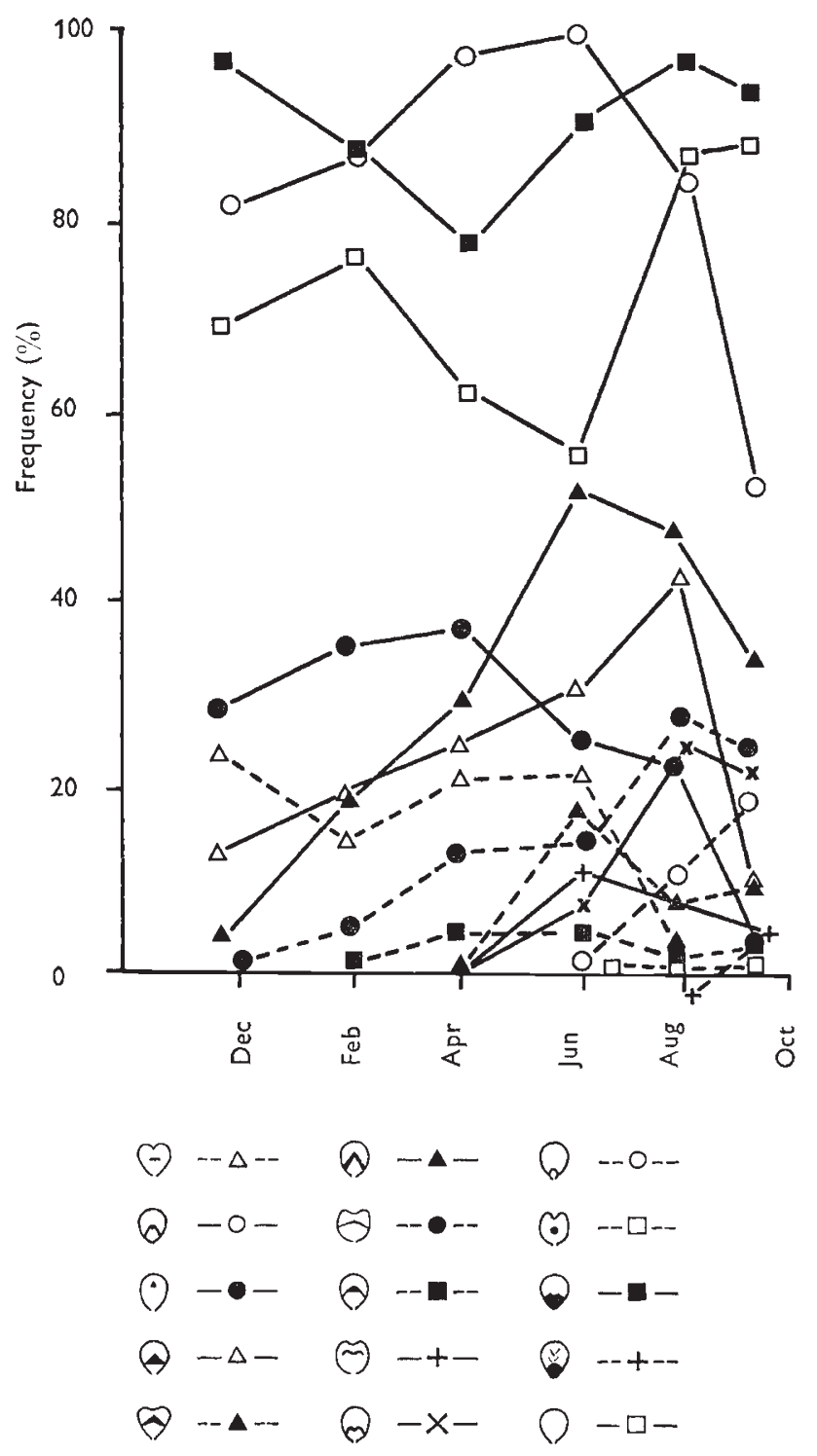

FIG. 2.-Seasonal variation in frequency of different morphs at site G1 at Henfaes, Aber, Gwynedd. The morphs recorded represent the minimum estimates (see text). 

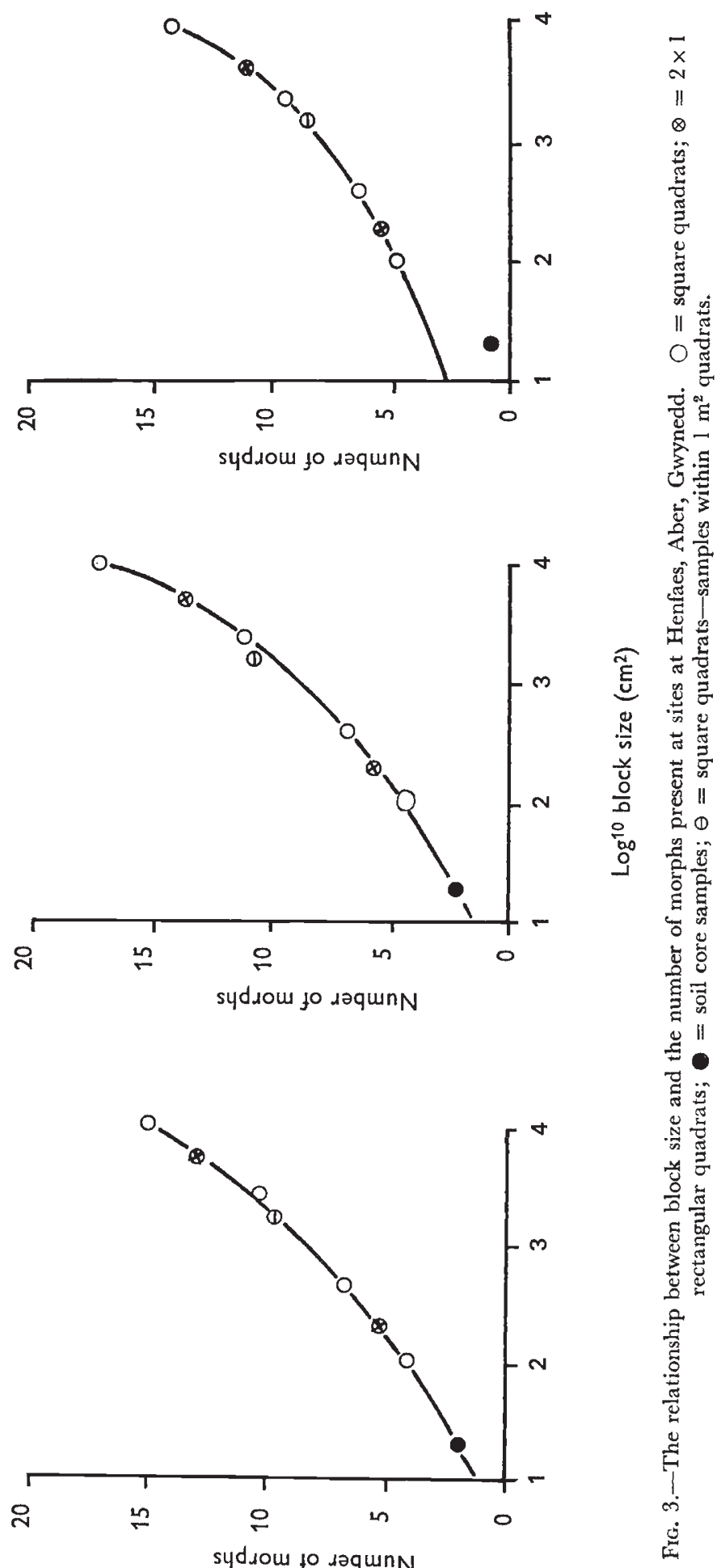

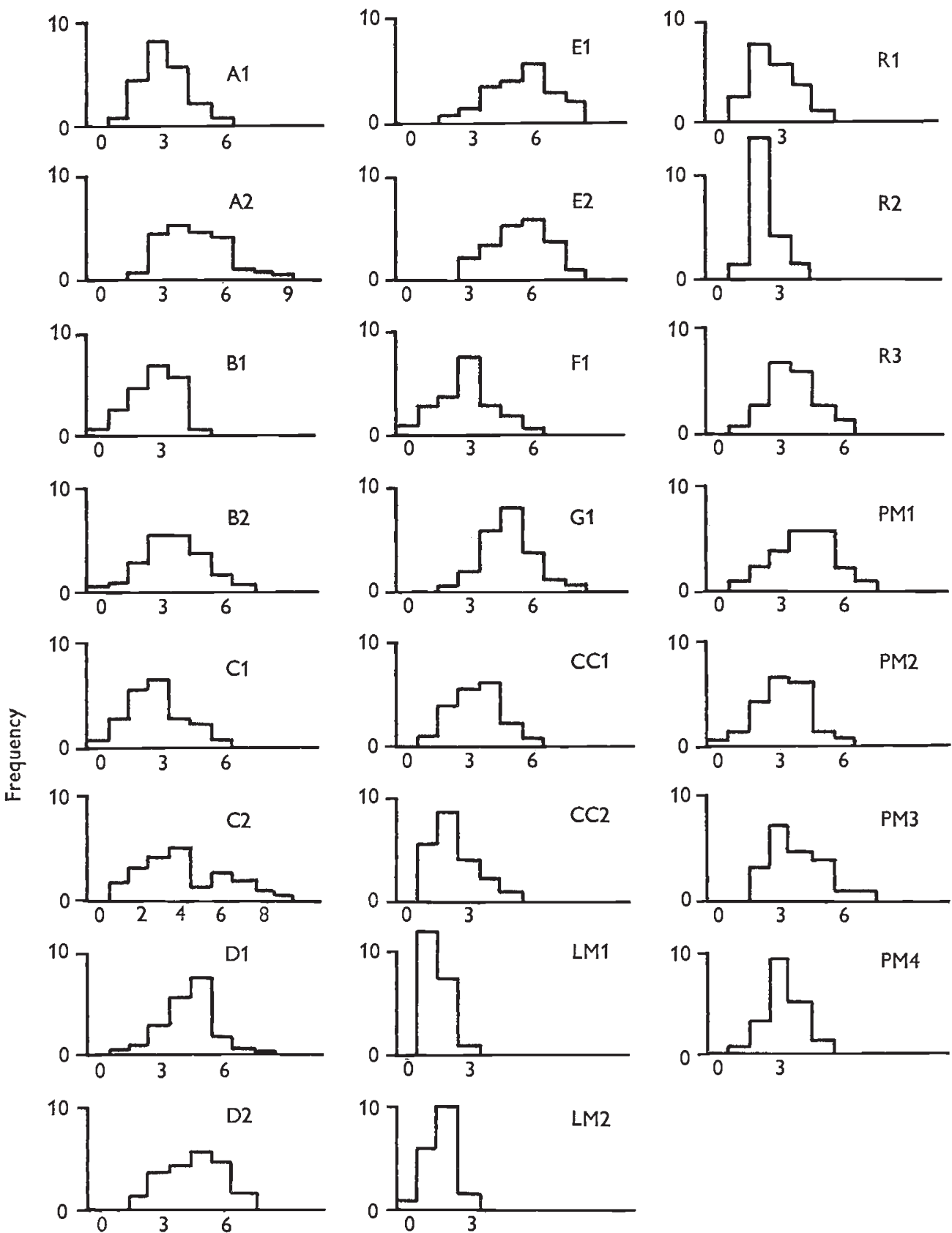

Number of morphs per quadrat $10 \times 10 \mathrm{~cm}$

Fig. 4.-The frequencies of $10 \mathrm{~cm}^{2}$ quadrats containing given numbers of morphs. A-G, Henfaes, Aber, Gwynedd. CC, Cae Cwrtiau, Aber, Gwynedd. LM, Lugg Meadow, Hereford. R, Walland Marsh, Rye, Sussex. PM, Port Meadow, Oxford. 
M. G. CAHN AND J. L. HARPER
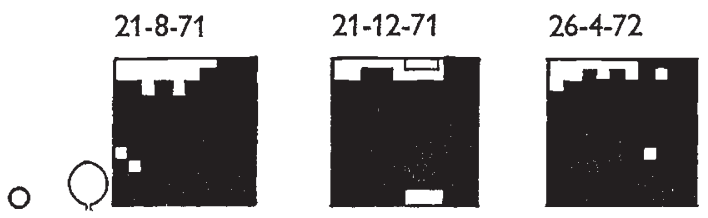

26-6-72

18-8-72

1 (4)
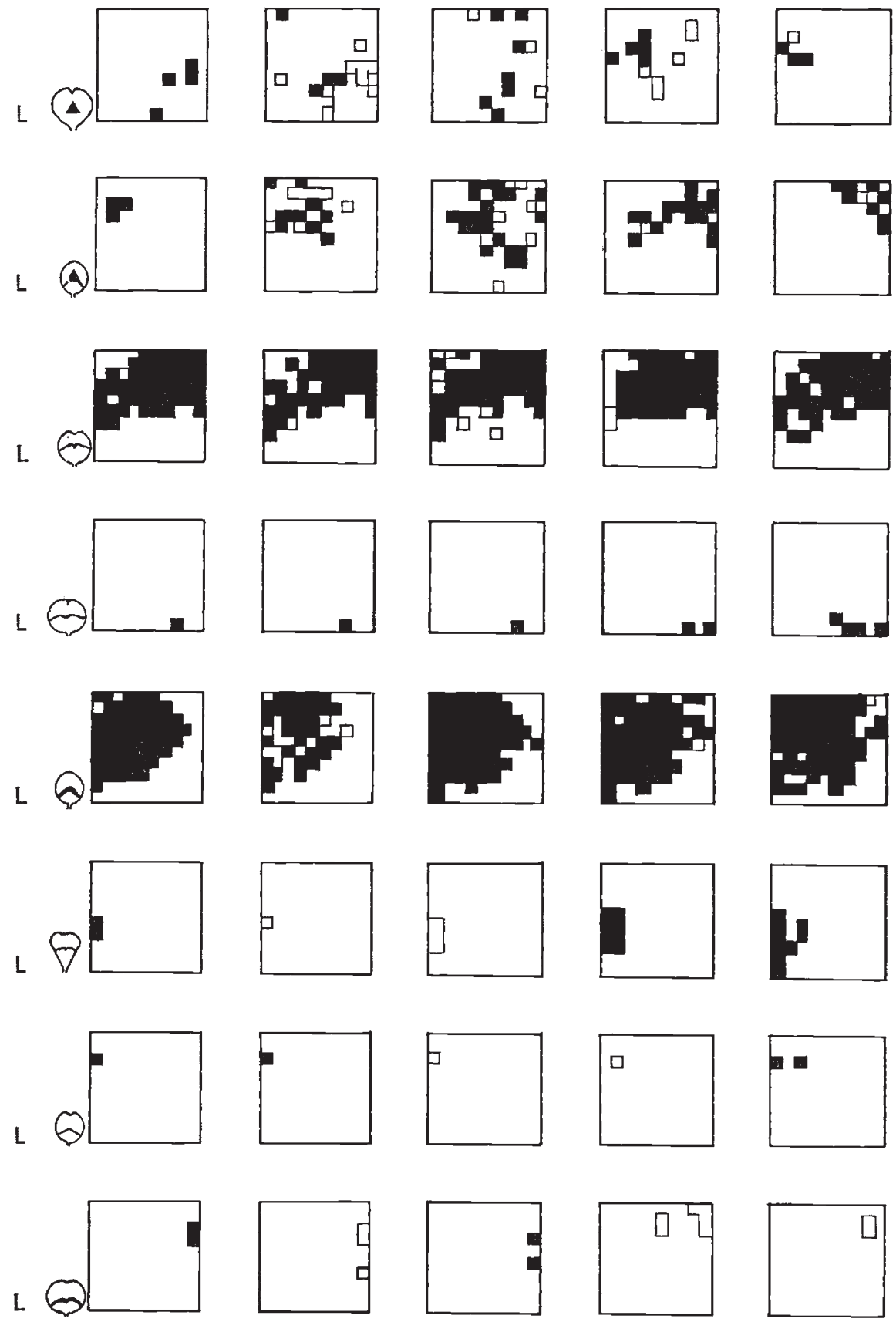
L
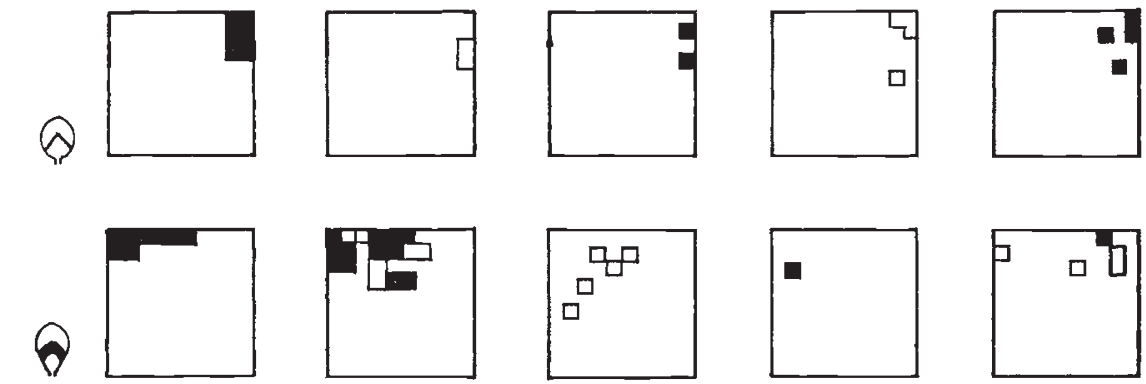

L
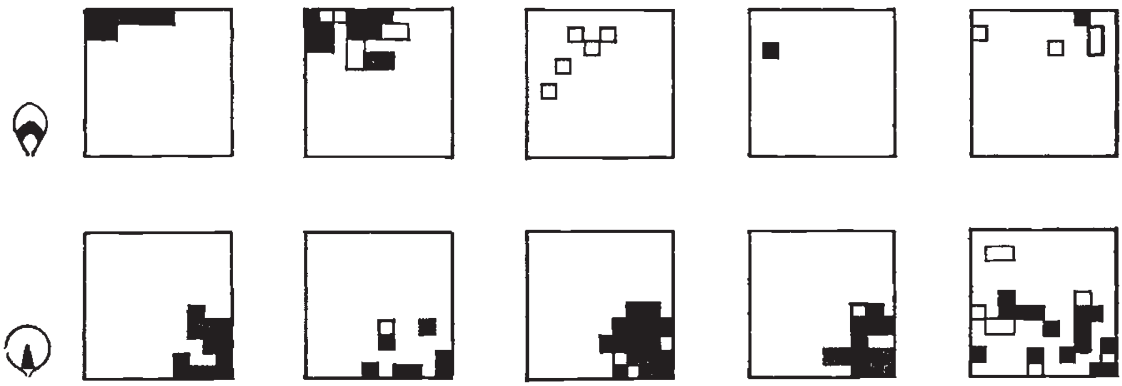

B
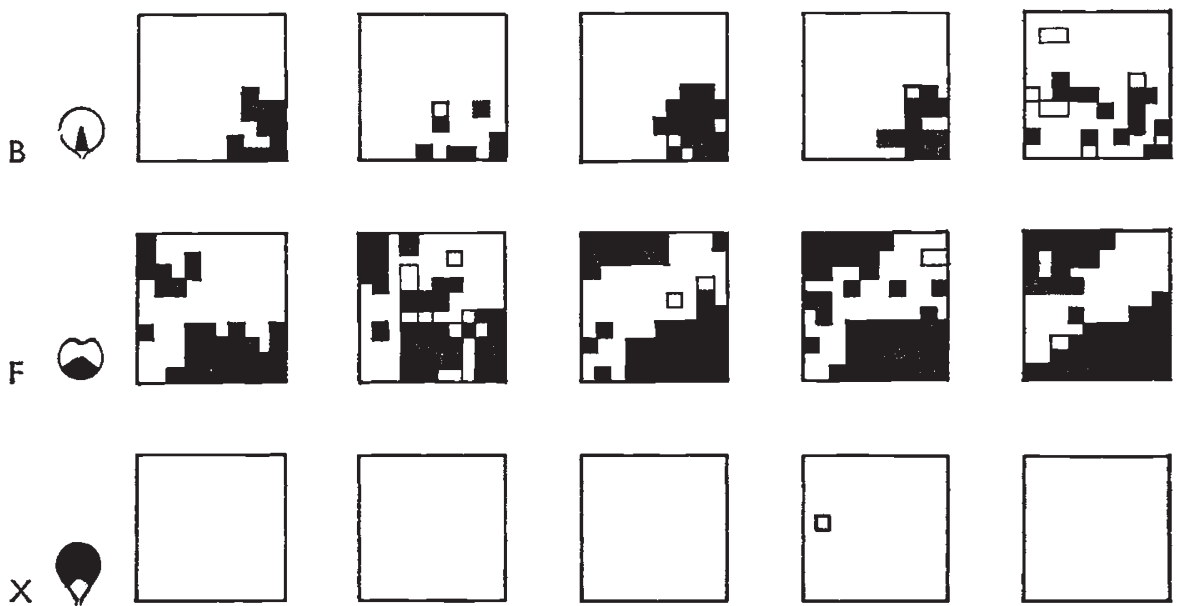

FIG. 5.-Maps of the distribution of clover leaf marks at site Al, Henfaes, Aber, Gwynedd indicating the distribution of each morph on the dates shown. Uncertain classifications are indicated by open squares. A picture of a leaflet of each morph is given to the left together with the corresponding phenotype abbreviation from table 1 .

clover-patches in areas of otherwise low clover density-it is likely that clover density was low in the core samples.

The frequency distribution of morphs in the hundred $10 \mathrm{~cm}^{2}$ subquadrats within each quadrat is shown in fig. 4. A surprisingly high number of recognisable morphs was present within the sub-quadrats. The frequency distributions of morphs per sub-quadrat have (with the exception of C2) a single mode, suggesting that there is reasonable homogeneity in leaf mark interspersion. G2 was unusual in that it contained a markedly high density of clover and intensity of grazing in one corner of the quadrat.

No obvious differences could be detected in the growth patterns of the different morphs in the field. Some of the individual clones were very extensive and presumably very old. One distinctive clone was present at two quadrats, E1 and E2, $10 \mathrm{~m}$ apart. This compares with a clonal spread of $18 \mathrm{~m}$ reported for T. repens growing on sand dunes (Harberd, 1963.) Some of the clones were very disjunct in their distribution while some occupied a restricted area with well-defined edges. However, the clonal spread of individual clones of the rare morphs (Broken Yellow (Y), Filled (F) and 
Basal (Ba)) was significantly smaller than that of the common ones (unmarked (O) and a simple mark (L)) (Cahn, 1976).

Maps of the clones found at one site in Henfaes field are given in fig. 5.* The size and pattern of distribution of the clones was similar in the different areas (Cahn, 1976).

\section{Discussion}

Plants that spread clonally have potentially infinite life and may be expected to prolong the process of competitive elimination of the unfit. Within a relatively stable community composed largely of clonally spreading species, the number of genotypes present might be expected to decline

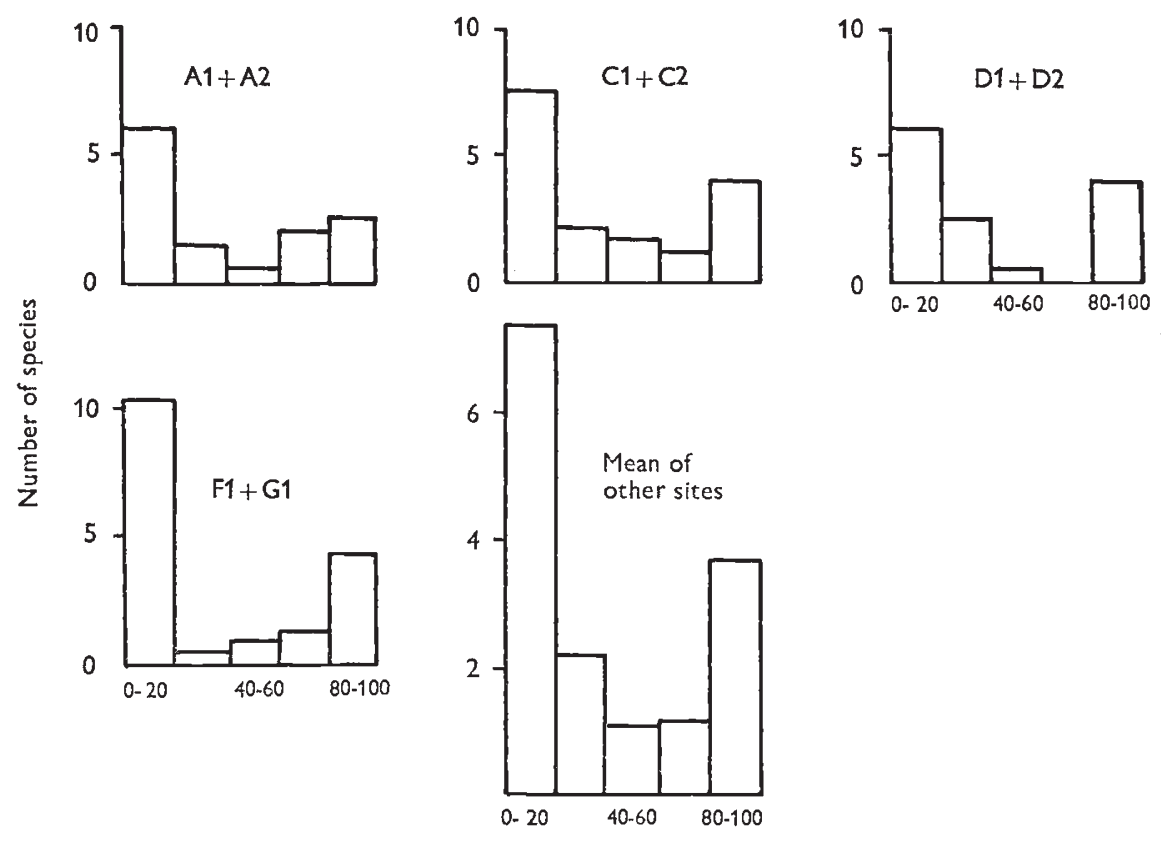

Frequency of occurrence

FIG. 6.-Raunkiaer diagrams for species at the various sites at Henfaes, Aber, Gwynedd. The horizontal axis is the percentage frequency in $1 \mathrm{~m}^{2}$ quadrats $(20$ per cent intervals).

continuously as the community ages. This has been shown clearly for grasses in sown pastures (Charles, 1964) and in an experimental study of populations of Lolium perenne (Kays and Harper, 1974) while Charles (1968) has shown that this occurs with $T$. repens in the establishment phase of a grass-clover ley. In permanent grassland the input of new genotypes through seedling establishment appears to be extremely rare for many perennial species, e.g. Rumex acetosa and $R$. acetosella (Putwain and Harper, 1968), Plantago spp. (Sagar and Harper, 1960). Within the studied quadrats only six seedlings of $\mathcal{T}$. repens

* A limited number of copies of maps of the clones found at all the sites studied are obtainable from M. G. C. 
were observed and these all died before forming established plants. Establishment of new plants of $T$. repens from seed was only observed to occur on mole hills. These represent small local uninhabited islands for new invasions.

In the absence of frequent input of new genotypes, local dominance by a few successful clones might be expected and this is indeed the situation found

10

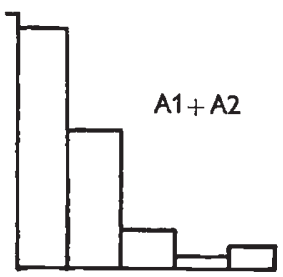

10

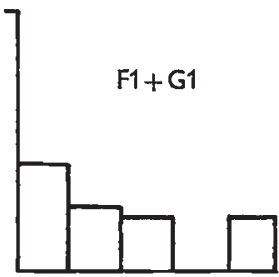

है

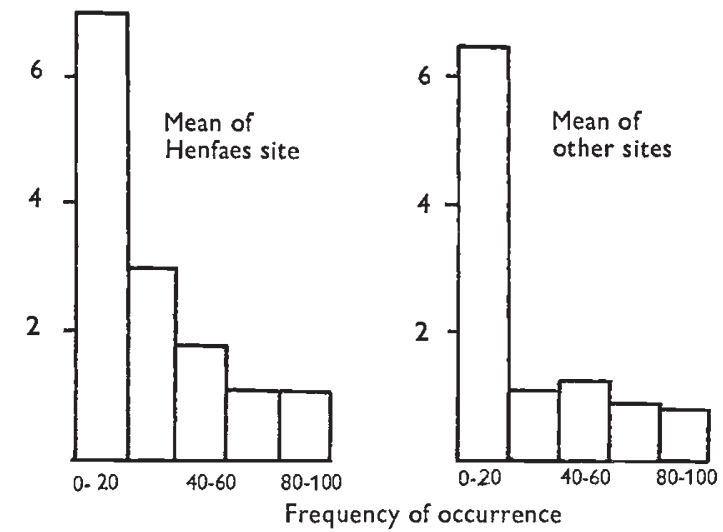

10

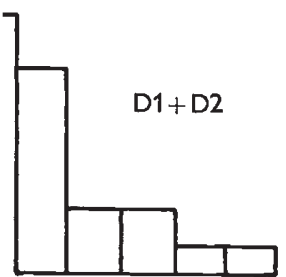

10

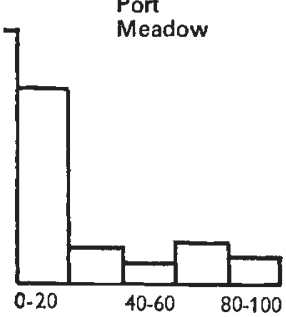

Fig. 7.-Raunkiaer diagrams for leaf mark morphs of $\mathcal{T}$. repens, at Henfaes, Aber, Gwynedd. The same $1 \mathrm{~m}^{2}$ quadrats were used for Henfaes sites as in fig. 6 . The minimum estimates of morphs are used (see text).

with some other species e.g. Erica spp. (Webb, 1954, 1958), Festuca ovina (Harberd, 1962) and Holcus mollis (Harberd, 1967). Populations of Lysimachia nummularium in Britain are believed to be derived from a very few incompatible clones (G. E. Marks, pers. comm.).

However, there is evidence that in some fertile lowland pastures a high diversity of clones may be maintained in some species. At Henfaes at the 
time of maximum mark clarity we found a mean frequency of 4.16 morphs per $10 \mathrm{~cm}^{2}$ and a mean frequency of 2.75 at Cae Cwrtiau, a 5-year-old clover/rye grass ley (table 3). Harberd and Owen (1969) found an average of 5.2 clones of Festuca rubra per $15 \times 15 \mathrm{~cm}$ quadrat in a water meadow at Barden Bridge, Yorks. Such a level of diversity is comparable to that reported for $T$. repens in the present paper. Pusey (1965) had found 1.99 clones of T. repens per $10 \times 10 \mathrm{~cm}$ quadrat in a $3.0 \times 1.2 \mathrm{~m}$ area of pasture near Oxford. There is, however, an important difference between the situation in Festuca rubra and in Trifolium repens. Harberd and Owen (1969) found that the lowest number of clones of Festuca rubra occurred in the areas of highest density of the species: this finding is compatible with a process of competitive exclusion of genotypes. By contrast the intermingling of the leaf marks of T. repens appeared in the present study to be greatest where clover density was high. The linear regression of morph number per quadrat against clover density on a five-point scale is positive $(\mathrm{P}<0.01, t=14.54)$ in the Henfaes field.

It is interesting to compare the diversity of morphs with the diversity of species-the contrast between intra- and interspecific diversity. A classical way of describing diversity within a plant community uses the Raunkiaer diagram (Raunkiaer, 1913, 1918). The procedure involves dividing the total number of species (or, in this case, morphs) within a community into classes according to their frequency of occurrence. When the percentage occurrence of species is plotted against frequency class, a characteristic J-shaped curve is usually obtained. This procedure has been criticised (Kylin, 1926; Greig-Smith, 1957) because the frequency classes do not represent equal ranges of density. Indeed, the highest frequency class includes a wider range of possible densities than the other frequency classes. This criticism is, however, irrelevant for the present purposes; what is important is that the procedure demonstrates a marked difference between the behaviour of species and that of morphs. Figs. 6 and 7 show Raunkiaer diagrams calculated for morphs of $T$. repens and for species in the Henfaes pasture. The species curves have the characteristic form of a Raunkiaer "Law of Frequencies" with the expected J-shaped curve: morph frequency is quite different and, instead of being J-shaped, shows a continuous decline in the percentage of morphs present in the classes of successively higher frequency. There is under-representation of morphs that occur at high frequency compared with a similar analysis made on species. There is less obvious dominance shown between clones than between species. In only one of the 12 sites at Henfaes (C2) was one clone clearly dominant. The general picture is of a number of intimately intermingled clones of $T$. repens, even in the extremely old (900 years) grassland at Port Meadow, Oxford.

There is a clear relationship between the frequency of marks and grass length. In the toe-point samples the data can be classified both according to the nature of the area (table 1) and by the length of the grass at the collection point. In Table $5 \mathrm{c}, 2 \times 2$ contingency tables are shown for each grazing régime and it is clear that a significant difference in the marked/ unmarked ratio can be found only at grazing regime 1, i.e. well-grazed areas.

Since the frequency of marked leaves is higher in short, well-grazed pasture, this suggests that marks provide some protection from grazing. If this is the case it might be expected that in ungrazed pastures there would be a few dominant clones and a low frequency of morphs. This hypothesis is 
difficult to test because if grassland is not regularly defoliated T. repens rapidly disappears. At Henfaes, site $\mathrm{C} 2$, the only site with a single dominant clone, grazing was relatively slight; there are relatively few clones at the Lugg Meadows site which is only grazed in the autumn when marks are not clearly expressed. In mown pastures or lawns where defoliation is not selective, but has been long continued, a convenient comparison could be made with the grazed condition. There seem, however, to be exceptionally few situations in which a regularly mown grassland has not been treated with selective herbicide. A subsequent paper describes experiments that suggest that the selective grazing of sheep may be sufficient to balance the leaf mark polymorphism of Trifolium repens in pastures and account for the fine ecological grain of the phenomenon.

Acknowledgments.-We are grateful to Mr David Machin, Mr E. R. B. Oxley and Mr M. O. Hill for help and advice in statistical and computer handling of the data, and also to the staff of College Farm, Aber, Gwynedd and Mr Pilcher of North Farm, East Guldeford, Rye, Sussex on whose land some of the work was done. This work was done while M.G.C. was in receipt of a National Environment Research Council Studentship.

\section{REFERENCES}

BREWBAKER, J. L. 1955. Leaf marking in white clover. F. Hered., 46, 115-121.

CAHN, M. G. 1976. Ph.D. Thesis, University of Wales.

CARNAHAN, H. L., HILl, H. D., HANSON, A. A., AND BROWN, K. G. 1955. Inheritance and frequencies of leaf markings in white clover. 7. Hered., 46, 109-114.

CharLeS, A. H. 1964. Differential survival of plant types in swards. 7. Br. Grassl. Soc., 19, 198-204.

ChARLES, A. H. 1968. Some selective effects operating upon white and red clover swards. 7. Brit. Grassl. Soc., 23, 20-25.

CORKILL, L. 1971. Leaf markings in white clover. 7. Hered., 62, 307-310.

GREIG-SMITH, P. 1957. Quantitative Plant Ecology. Butterworth, London.

HARberd, D. J. 1962. Some observations on natural clones of Festuca ovina. New Phytol., 61, $85-100$.

harberd, D. J. 1963. Observations on natural clones of Trifolium repens L. New Phytol., 62, 198-204.

HARBERD, D. J. 1967. Observations on natural clones in Holcus mollis. New Phytol., 66, 401-408.

HARBERD, D. J., AND OWEN, M. 1969. Some experimental observations on the clone structure of a natural population of Festuca rubra. New Phytol., 68, 93-108.

KAYS, S., AND HARPER, J. L. 1974. The regulation of plant and tiller density in a grass sward. 7. Ecol., 62, 97-105.

кyLIN, н. 1926. Uber Begriffsbildung und Statistik in der Pflanzen-soziologie. Bot. Notiser. (1926), 81-180.

PUSEY, J. 1965. D.Phil. Thesis, University of Oxford.

PUTWAIN, P. D., AND HARPER, J. L. 1968. Components and regulation of a natural population of Rumex acetosella L. 7. Ecol., 56, 421-431.

RAUNKIAER, c. 1913. Formationsstatistike undes paen skagens odde. Bot. Tids., 33, 197-228.

RAUNKIAER, c. 1918. Recherches statistiques sur les formations vegetales. Det. kgl. Danske Videnskab. selskab. Biol. Medd., 1.

SAGAR, G. R., AND HARPER, J. L. 1960. Factors affecting the germination and early establishment of plantains (Plantago lanceolata, P. media, P. major). In Biology of Weeds, ed. J. L. Harper. Blackwell, Oxford.

SARUKHÁN, J., AND HARPER, J. L. 1973. Studies on plant demography: Ranunculus repens L., Ranunculus bulbosus L. and Ranunculus acris L. 1. Population flux and survivorship. 7. Ecol., 61, 675-716.

WEBB, D. A. 1954. Notes on four Irish heaths. Part I. Irish Naturalist, 11, 187.

webB, D. A. 1958. Notes on four Irish heaths. Part II. Proc. Bot. Soc. Brit. Isles., 3, 105. $37 / 3-B$ 